\title{
FaCUldade de Formação de Professores
}

\section{AUTO: COMUNHÃO DO SAGRADO E PROFANO}

\author{
Rosângela Divina Santos Moraes da Silva \\ rosangeladsms@yahoo.com.br
}

$\mathrm{O}$ auto (jeux: denominação genérica das primeiras peças que surgem a partir do século XII em França) tornou-se uma das modalidades dramáticas das mais utilitárias no teatro religioso medieval, tendo espaço privilegiado nas moralidades (também conhecidas como auto alegóricos). A partir do final da Guerra dos Cem anos, os jeux diversificam-se e multiplicam-se.

Dessa forma, muito cedo os autos alegóricos, sacramentais e as peças de lendas ganharam a praça do mercado. Por conta da ascensão da população urbana europeia e da quebra do monopólio clerical das celebrações religiosas, esses autos alegóricos, de moralidades e de milagres dividem espaço com os grêmios e corporações que financiam os espetáculos. Os acessórios e figurinos cênicos passam agora às mãos da burguesia e dos artesãos.

Segundo Margot Berthold (2003, p. 203), há uma fusão entre o caminho da celebração litúrgica, encetado e incentivado pela Igreja, e o da população urbana europeia ascendente. Cabe-nos ressaltar que, nessa fusão, as encenações religiosas não se restringem à representação de passagens do Evangelho, servem-se, contudo, de outros temas, como o das Cruzadas, para reforçar o dogmatismo cristão.

Apesar de os textos dos Evangelhos terem sido uma relevante fonte de matéria-prima para as representações religiosas, outros fatores tornaram-se elementos indispensáveis ao teatro europeu no século XII. Figurinos, motivos grotescos e farsescos revelaram-se também em referenciais da dramatização religiosa na igreja e da crítica social contemporânea, propiciando um estilo mais realista de representação devido as mudanças que estavam acontecendo na época. (Berthold, 2003, p. 203)

A exemplo disso, podemos citar a peça Antichristo de Tegernsee, século XII, de autor anônimo, que reflete o movimento cruzadístico, nas cenas em que mostram o declínio do Império Romano e triunfo do germânico. Cenas essas que precedem os fatos ligados diretamente ao Anticristo, um falso messias enviado por Satanás que reúne todos os poderes malignos na luta contra a Igreja Cristã: 


\title{
DEPARTAMENTO DE LETRAS
}

\begin{abstract}
A peça reflete o apogeu do espírito das Cruzadas na época de Barbarossa [...]. De acordo com fontes conservadas, o Ludus de Antichristo, era representado por clérigos. Seu texto é escrito em latim, e apesar de suas preocupações claramente políticas, preserva o caráter oratório da representação eclesiástica. (Berthold, 2003, p. 203)
\end{abstract}

Vilma Arêas, em Iniciação à comédia (1990, p. 42-44), ratifica e assegura que o teatro medieval desenvolve-se, também, pela liturgia cristã, principalmente nas celebrações da Páscoa, tendo sido um processo lento e desigual, mantendo-se como o meio principal de instrução religiosa para a grande massa da população iletrada, enquanto o latim permaneceu como linguagem universal de cristandade.

A partir da introdução do vernáculo, no lugar do latim, e com a passagem das representações de dentro para fora da igreja, abriu-se o caminho para o desenvolvimento do teatro nacional em cada país, pois a partir do estabelecimento da língua vulgar houve um rompimento do auto pascal com a liturgia. Ao abrir as suas portas, a Igreja contribuiu significativamente para a ampliação não só do espaço cênico, como também se abriu espaço dando liberdade para que as pessoas do povo apresentarem as verdades reveladas conforme a própria interpretação da vida.

Não se pode, portanto, definir com exatidão quando do surgimento das encenações profanas pela Europa, pois essas produções foram acompanhadas da substituição do latim pela língua oficial de cada país, bem como da inserção de cenas cômicas a episódios religiosos. Por exemplo, "a mulher de Noé aparece como uma virago que surra o marido e que deseja levar todas as amigas para arca" (Arêas, 1990, p. 44).

Para Lígia Vassalo (1983, p. 43), o teatro profano tem ligação com o cômico e não aparece como forma independente antes do séc. XIII. Não se sabe de onde ele provém, tendo uma influência significativa quando a encenação sai da Igreja.

O deslocamento da ação para outro espaço cênico, ao redor da igreja, devido a inserção do episódio da descida de Jesus ao inferno, nas representações dos autos do Juízo final, propiciou o surgimento das sátiras seculares das corporações e das encenações profanas da Dança da Morte. 


\section{FaCUldade de FormaÇão de Professores}

Margot Berthold (2003, p. 198) assegura que se estabelece um elo entre a Redenção do Novo Testamento e a Criação no Velho, com a descida de Jesus Cristo ao Inferno. Essa junção, para os iniciadores do drama litúrgico, provocou um deslocamento "efetivo do lugar da ação". Surgem as procissões dos atores "ao redor da igreja até o pórtico", simbolizando "os portões do limbo", em que todos participam da encenação e "entram juntos na igreja, seguidos pela congregação". Desse modo, a partir do momento que o auto retratando o Juízo Final desvinculou-se do cenário sacro, muito rápido se chegou às representações das sátiras seculares das corporações e das profanas da Dança da Morte que, nas velhas crenças populares, a Morte é personificada e força os vivos a segui-la em seu séquito, independentemente de idade, sexo ou condição social, em orgias noturnas dos mortos.

O termo profano advém do fato de os Concílios Sinodais instituírem regras disciplinadoras para cada diocese, as quais proibiam as igrejas de promoverem nos recintos sagrados manifestações profanas, incluindo a dança e o canto. Os pátios, os arredores das Igrejas tornam-se o espaço de dramatizações profanas, ligadas ao cômico popular. A partir disso, estendem-se aos burgos, aos mercados e feiras, chegando às cortes reais e senhoriais.

Muito embora fossem proibidas, algumas manifestações profanas são autorizadas a se realizar nos templos sacros, à época das grandes festas, cujo espírito fosse representar a piedade e devoção. Nesse sentido, a autoridade eclesiástica permitia o canto, o jogo e a dança, por ocasião do Natal e das festas dos Reis, porém condenava quaisquer divertimentos, tidos como irrespeitosos, nos lugares santos. No entanto, como afirma Lígia Vassalo (1983, p. 43) a literatura oral é explorada pelos "jograis-mímicos profissionais que recitam, cantam, executam monólogos dramáticos e mímicas dialogadas", que encantam com as imitações de tipos bêbados, tolos, loucos, nas feiras, nas praças, o que os tornam filhos e transmissores da antiga tradição latina.

O florescimento das produções profanas tem seu início no séc. XIII, nos centros urbanos, pela burguesia culta e rica, cujos precursores são Jean Bodel e Adam de La Halle, oferecendo uma variedade de gêneros. A intensificação dessas produções dá-se no séc. 


\section{DEPARTAMENTO DE LETRAS}

$\mathrm{XV}$, logo depois da Guerra dos Cem anos, quando surgem diversas Confrarias responsáveis pelas encenações.

Segismundo Spina, em Iniciação na cultura literária medieval (1973, p. 17), demonstra que as produções de intenção pedagógica, missionária, de moral religiosa denominam-se de literatura empenhada (Baixa Idade Média - sécs. XII-XV). Já a literatura de moral profana, semi-empenhada, em que se destacam as farsas, as sotties (sotia) e os sermões burlescos.

A farsa tem suas origens nas festas dos bufões e nas recitações dialogadas dos menestréis. Trata-se de uma peça curta do teatro profano, que visa ao riso fácil, sem pretensões didáticas ou moralizantes. O riso é provocado pelo exagero de fatos, de comportamentos cotidianos, evidenciando o povo. Não há, nessa modalidade teatral, o desejo de se edificar o ser humano, nem tampouco moralizá-lo através da alegoria.

De acordo com Margot Berthold (2003, p. 255), o marco inicial desse tipo teatral é a obra Maître Pierre Pahtelin, de escritor desconhecido, representada pela primeira vez por volta de 1465 , cujo tema é a trapaça em um negócio. Entretanto a crítica aponta o edito de Preboste de Paris, de 1398, como prova histórica da origem da farsa.

No gênero farsesco, a crítica social e a sátira têm lugar reservado. Os diálogos de Maitre Pierre, por exemplo, são mordazes, as frases sofisticadas, polidas, desembocam em brincadeiras grosseiras que comprometem a classe dos advogados. Muitos autores, dentre eles Rabelais e Grimmelshausen, apropriaram-se desse estilo de farsa.

Às associações de juristas conhecidas como Basoches devem as melhores farsas em originalidade. As Basoches estabeleceram-se em Paris e nas províncias durante o século XIV, realizando anualmente reuniões entretidas por pequenos diálogos farsescos e pantomimas, de cenas de casos jurídicos fictícios. Tal fato explica-se por ser os fundadores da farsa, "advogados e escritores, estudantes e associações cênicas de cidadãos, eruditos errantes, mercadores e artesãos" (Berthold, 2003, p. 256).

A inescrupulência da farsa é o motivo de sua eficácia: a autoironia, a zombaria, a impudência com que são representados os con- 


\section{FaCUldade de FormaÇão de Professores}

flitos políticos, os abusos correntes, estes dissimulados em alegorias inofensivas. Portanto, o espaço cênico da farsa dispensa técnicas especiais. O que importa é a astúcia verbal das representações de situações e personagens cômicas.

Nesse sentido, a teatralidade da farsa não pode nunca confundir-se com os parâmetros da comédia, por exemplo, seja ela noticiosa e celebrativa, seja ela fantasiada. Independentemente de a estrutura ser de desfile ou intriga concentrada, o que conta no estilo farsesco é a artimanha que serve para opor sabidos a ingênuos e a verossimilhança de base caricatural que visa criar efeitos de cômico e de realidade. (Bernardes, 2003, p. 126)

Entre a farsa e a sottie é quase impossível estabelecer uma diferença, pois ambos os estilos servem igualmente à diversão do público. Nos Entremeses, "os heróis da farsa são truões em trajes comuns ou cortesãos; já os heróis da sottie são gente comum ou da corte em vestimenta de bobo" (Berthold, 2003, p. 257). Assim como a farsa, a sottie é também uma peça curta, cujos personagens são loucos ou bobos da corte que, investidos da loucura, permitem-se fazer críticas a fatos históricos e políticos, ou ridicularizar valores preestabelecidos pela sociedade vigente.

Quanto aos sermões burlescos, trata-se de monólogos enunciados por atores representando frades. Nesse tipo de peça, parodiamse elementos do ritual litúrgico, como orações, hinos, ladainhas e sermões: o gênero caracteriza-se pela paródia às instituições religiosas. Famoso é o Panegírico de Santo Arenque, Santo Presunto e Santo Chouriço, monólogo bufo que caricatura os sermões eclesiásticos" (Vassalo, 1983, p. 45).

Esse esboço do drama medievo e suas variações estéticas não se prefigura em uma compartimentação rígida de gêneros e espécies literárias do teatro medieval, pois os sabemos polivalentes, mesclados. Paul Teyssier (1982, p. 33) demonstra essa ambivalência ao se referir a uma categoria de espetáculos conhecida por momos, a qual desempenhou considerável e importante papel na gênese do teatro de Gil Vicente.

Os momos, encenações carnavalescas, de temática muito variada, apresentando personagens mascarados, surgem em Portugal no início do século XV, já vulgarizados por toda a Europa. Esses espetáculos realizavam-se nas festas aristocráticas, em ocasiões solenes, das quais participavam altas personalidades (reis e príncipes), em 


\section{DEPARTAMENTO DE LETRAS}

que se fazia exibição de luxo, cujos figurantes vestiam-se com trajes especiais e usavam máscaras.

Gil Vicente acrescenta a essa modalidade o texto falado, uma vez que a parte falada dos momos iniciais limitava-se a um texto escrito que as personagens entregavam umas às outras.

De acordo com Paul Teyssier (1982, p. 35), todas as manifestações - os momos, os entremezes das festas públicas ou as representações litúrgicas atrás mencionadas - só são da esfera do teatro pelo lado do espetáculo. Para que o espetáculo seja um verdadeiro teatro, torna-se necessária a inserção do diálogo das personagens e, consequentemente, o acréscimo de toda a dimensão linguística e literária.

Entendiam-se por momos, as máscaras, as vestimentas, os acessórios, as personagens e a própria representação. "Apesar do termo momo reportar ao deus romano da zombaria" (Mongeli, 1992, p. 192), a representação caracterizava-se de forma semelhante à procissão pelo aspecto alegórico e espetaculoso, galante e solene, próprio à temática desenvolvida, "que compreendia matéria cavaleirescoexpansionista". E, devido à "escassez ou a inexistência de discursos e da ação dramática", a dança e a mímica, "além de vários recursos técnicos, de muitas maquinarias e seus truques", passam a ser utilizadas, o que provoca surpresa e admiração nos espectadores.

Vemos que Mongelli e outros autores consideram os entremezes $^{1}$ um entreato do momo, enquanto que Paul Teyssier parece considerá-los sinônimos. Já Lígia Vassalo (1983, p. 46) define-o como uma peça curta, de um ato, sketch cômico, burlesco e jocoso, de caráter popular ou palaciano, que termina geralmente por um número musical cantado.

Outra modalidade dramática ligada à origem do teatro medieval é o arremedilho ou arremedo, uma imitação cômica de pessoas ou de acontecimentos, cujas raízes estão em um documento de 1193 que faz referência a uma doação de terras aos bufões Bonamis e Acompanhado por Sancho I, os quais lhe prometeram um arremedilho.

${ }^{1}$ Também conhecido por entreato, intermezzo, interlúdio, o termo entremez designa genericamente qualquer tipo de entretenimento encenado entre atos ou as partes de uma peça maior. Pode tomar forma de peças curtas, sketches, números circenses ou de pantomima ou números musicais. 


\section{FaCUldade de FormaÇão de Professores}

No tempo do reinado de Afonso X de Castela, os bufões ou jogral que acompanhavam a declamação mímica eram conhecidos como remedadores, sendo o espetáculo, por eles proporcionado, o arremedilho. O termo ganha amplitude semântica de arremedação, como sinônimo de representação ou comédia, vigorando até o século XVI.

Convém ressaltarmos que o teatro português medieval de Gil Vicente caracteriza-se pela versatilidade de suas peças, as quais podem ser consideradas tanto religiosas quanto profanas ou uma mescla de contextos em que prevalecem o sagrado e o profano, sendo o auto uma modalidade dramática marcante dessa versatilidade.

\section{REFERÊNCIAS}

ARÊAS, Vilma. Iniciação à comédia. Rio de Janeiro: Jorge Zahar, 1990. Coleção Letras.

BERNARDES, José Augusto Cardoso. Gil Vicente. Coimbra: Edições 70, 2008.

Sátira e lirismo no teatro de Gil Vicente I e II. $2^{\mathrm{a}}$ ed. Lisboa: Imprensa Nacional, 2006.

—. Revisões de Gil Vicente. Coimbra: Angelus Novus, 2003.

BERTHOLD, Margot. História mundial do teatro. São Paulo: Perspectiva, 2003.

MONGELLI, Lênia Márcia de Medeiros et alii. A literatura portuguesa em perspectiva: trovadorismo e humanismo. São Paulo: 1992, vol. 1.

SPINA, Segismundo. Iniciação na cultura medieval. Rio de janeiro: Grifo, 1973. Coleção síntese, vol. 1.

TEYSSIER, Paul. Gil Vicente - o autor e a obra. Tradução Álvaro Salema. Lisboa: Instituto de Cultura e Língua Portuguesa, 1982. Coleção-Biblioteca Breve - série literatura.

VASSALO, Lígia. O teatro medieval. In. CASTRO, Manuel Antonio. Teatro sempre. Rio de Janeiro: Tempo Brasileiro, 1983.

O grande teatro do mundo. In. Caderno de Literatura Brasileira. Instituto Moreira Sales, $\mathrm{n}^{\circ}$ 10, novembro, 2000. 